\title{
Does Smoking Impair Bone Regeneration in the Dental Alveolar Socket?
}

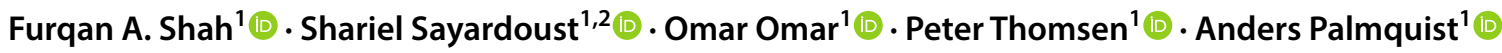

Received: 24 June 2019 / Accepted: 27 August 2019 / Published online: 18 September 2019

(c) The Author(s) 2019

\begin{abstract}
Smoking is a major risk factor for dental implant failure. In addition to higher marginal bone loss around implants, the cellular and molecular responses to injury and implant physicochemical properties are also differentially affected in smokers. The purpose of this work is to determine if smoking impairs bone microstructure and extracellular matrix composition within the dental alveolar socket after tooth extraction. Alveolar bone biopsies obtained from Smokers ( $>10$ cigarettes per day for at least 10 years) and $C t r l$ (never-smokers), 7-146 months after tooth extraction, were investigated using X-ray micro-computed tomography, backscattered electron scanning electron microscopy, and Raman spectroscopy. Both Smokers and Ctrl exhibited high inter- and intra-individual heterogeneity in bone microstructure, which varied between dense cortical and porous trabecular architecture. Regions of disorganised/woven bone were more prevalent during early healing. Remodelled lamellar bone was predominant at longer healing periods. Bone mineral density, bone surface-to-volume ratio, mineral crystallinity, the carbonate-to-phosphate ratio, the mineral-to-matrix ratio, the collagen crosslink ratio, and the amounts of amino acids phenylalanine and proline/hydroxyproline were also comparable between Smokers and Ctrl. Bone microstructure and composition within the healing dental alveolar socket are not significantly affected by moderate-to-heavy smoking.
\end{abstract}

Keywords Bone $\cdot$ Smoking habit $\cdot$ Alveolar process $\cdot$ Extracellular matrix $\cdot$ Bone regeneration $\cdot$ Raman spectroscopy

\section{Introduction}

Smoking is a global health problem, with increased healthcare and societal costs owing to diminished healing capacities and risk of with premature mortality $[1,2]$. In 2012 alone, the global cost of smoking-attributable diseases (excluding second-hand smoking) was equivalent to 5.7\% of the global health expenditure [3]. In addition to being a risk factor for poor bone mineral density [4] and increased cortical porosity [5], the effects of smoking on periodontal health are well-documented [6, 7]. Although dental rehabilitation using osseointegrated implants is a reliable treatment

Furqan A. Shah and Shariel Sayardoust have contributed equally to this work.

Furqan A. Shah

furqan.ali.shah@biomaterials.gu.se

1 Department of Biomaterials, Sahlgrenska Academy, University of Gothenburg, Gothenburg, Sweden

2 Department of Periodontology, Institute for Postgraduate Dental Education, Jönköping, Sweden modality with high survival rates $[8,9]$, smoking can modulate the expression of osteogenic and inflammatory factors in alveolar bone [10], implant-adherent cells [11], and in the peri-implant crevicular fluid $[12,13]$. Consequently, dental implant failures are more prevalent in smokers [14-16], particularly prior to functional loading [17]. Smoking is implicated in an increased number of periodontally diseased sites [18], greater vertical periodontal bone loss [19], and periimplant/marginal bone loss [20]. Exposure of peri-implant tissues to tobacco smoke [21] and compromised blood supply during early healing [22] have also been proposed as the mechanisms underlying implant failure in smokers. It is hardly surprising that smoking also changes the peri-implant microbiome [23]. Experiments conducted in rats indicate diminished bone-implant contact and bone area due to inhalation of cigarette smoke [24-26]. Smoking has also been implicated in decreased width and radiographic density of the dental alveolar socket, 6 months after tooth extraction [27]. However, it is not known whether smoking also impairs bone regeneration within the dental alveolar socket and/or induces alterations in extracellular matrix composition, e.g. defective mineral phase, changes in the secondary 
structure of collagen, and atypical variations in mineral content. For this purpose, bone biopsies obtained between 7 and 146 months after tooth extraction were investigated using Raman spectroscopy in addition to X-ray micro-computed tomography (micro-CT) and backscattered electron scanning electron microscopy (BSE-SEM). It is demonstrated, for the first time, that the extracellular matrix composition of the healed site is not affected significantly by smoking, and therefore poor bone quality at the implant recipient site may be disregarded as a potential explanation for implant failures in moderate-to-heavy smokers.

\section{Materials and Methods}

\section{Bone Specimens and Inclusion Criteria}

The study subjects were selected from patients referred to the Department of Periodontology, Institute for Postgraduate Dental Education, Jönköping, Sweden, between January 2016 and January 2017, in accordance with the following inclusion criteria: Smokers were individuals who had smoked an average of $>10$ cigarettes per day for at least 10 years, and $C t r l$ were never-smokers by history. Additional requirements were: $(i)$ adequate volume of alveolar bone for implant placement, according to the Lekholm and Zarb classification [28], (ii) absence of risk factors that may affect levels of bone-related gene expression, including osteoporosis, chronic use of anti-inflammatory agents, use of bisphosphonates, or severe metabolic diseases such as diabetes, and (iii) a minimum of 6 months between tooth extraction and implant placement. Partially or completely edentulous individuals were not excluded. From 32 systemically healthy individuals (Table 1), cylindrical, $2 \times 3 \mathrm{~mm}$, alveolar bone biopsies were obtained under local anaesthesia from premolar regions, during implant site preparation, using a trephine drill and were immediately immersed in $10 \%$ neutral buffered formalin, followed by dehydration in a graded ethanol series (50-100\%) and resin embedding (LR White, London Resin Co. Ltd., UK). The study protocol was approved by the Institutional Review Board at the University of Linköping (Dnr 2016/319-31). Informed consent was obtained from all participants. The study was conducted in accordance with the guidelines of Good Clinical Practice for Trials on Medicinal Products in the European Community, the International Conference on Harmonisation (ICH) guideline for Good Clinical Practice, the Declaration of Helsinki, and the CONSORT guidelines for clinical studies. Post-extraction healing times (mean values \pm standard deviation) of Smokers ( $n=16 ; 38 \pm 21$ months) and $\operatorname{Ctrl}(n=16 ; 49 \pm 31$ months) were comparable $(p=0.209)$.
Table 1 Patient demographics and sample details

\begin{tabular}{llllll}
\hline Group & $\begin{array}{l}\text { Sample } \\
\text { code }\end{array}$ & $\begin{array}{l}\text { Healing time } \\
\text { (months) }\end{array}$ & $\begin{array}{l}\text { Age } \\
\text { (years) }\end{array}$ & Gender & Jaw \\
\hline Smokers & H375 & 7 & 47 & M & Maxilla \\
& H376 & 7 & 45 & M & Mandible \\
& H431 & 7 & 66 & M & Mandible \\
H429 & 10 & 44 & M & Maxilla \\
H428 & 16 & 67 & M & Maxilla \\
H361 & 37 & 40 & M & Mandible \\
H393 & 46 & 59 & M & Maxilla \\
H389 & 48 & 62 & M & Maxilla \\
H390 & 48 & 60 & M & Maxilla \\
H430 & 48 & 46 & M & Maxilla \\
H398 & 48 & 62 & M & Mandible \\
H409 & 48 & 52 & F & Mandible \\
H410 & 48 & 36 & F & Mandible \\
H422 & 48 & 49 & F & Mandible \\
H423 & 60 & 50 & F & Mandible \\
H432 & 74 & 65 & M & Mandible \\
H399 & 9 & 71 & F & Maxilla \\
H404 & 14 & 56 & M & Maxilla \\
H425 & 15 & 55 & F & Mandible \\
H374 & 32 & 68 & F & Maxilla \\
H387 & 48 & 54 & M & Maxilla \\
H400 & 48 & 35 & F & Maxilla \\
H405 & 48 & 52 & F & Maxilla \\
H377 & 48 & 68 & F & Mandible \\
H388 & 48 & 50 & M & Mandible \\
H392 & 48 & 52 & F & Mandible \\
H394 & 48 & 70 & M & Mandible \\
H395 & 48 & 72 & M & Mandible \\
H424 & 60 & 56 & M & Maxilla \\
H426 & 60 & M & Maxilla \\
H427 & 60 & 146 & M & Mandible \\
H397 & & Maxilla \\
\hline
\end{tabular}

\section{Bone Microstructure}

Bone mineral density (BMD) and bone surface-to-volume ratio $(\mathrm{BS} / \mathrm{BV})$ were evaluated using $\mathrm{X}$-ray micro-computed tomography (micro-CT). In a Skyscan 1172 (Bruker micro-CT, Kontich, Belgium) operating at $49 \mathrm{kV}$ energy with an $\mathrm{Al}$ filter $(0.5 \mathrm{~mm})$, all samples were scanned over a $180^{\circ}$ rotation at a step size of $0.5^{\circ}$ with an average of four frames and an image pixel size of $7.92 \mu \mathrm{m}$. BMD calibration phantoms $\left(0.25 \mathrm{~g} / \mathrm{cm}^{3}\right.$ and $0.75 \mathrm{~g} / \mathrm{cm}^{3}$ stoichiometric hydroxyapatite in epoxy resin, $2 \mathrm{~mm}$ diameter) were scanned using the same settings. Reconstruction, analysis, 
and visualisation were performed using associated Skyscan software (NRecon, Image viewer, CTVox, CTAn).

Resin embedded blocks were wet polished using 400-4000 grit $\mathrm{SiC}$ paper for backscattered electron scanning electron microscopy (BSE-SEM) in a Quanta 200 environmental SEM operated at low vacuum, $20 \mathrm{kV}$ accelerating voltage, $10 \pm 0.1 \mathrm{~mm}$ working distance, $40 \mu \mathrm{m}$ objective aperture, $\times 100$ magnification, and $2048 \times 1768$ pixels (pixel size $=1.26 \mu \mathrm{m}$ ). The extraction voltage and emission current were closely monitored. Brightness and contrast levels were kept constant throughout. Low Z- (atomic number) contrast features arising from the embedding medium were removed by applying a mean filter (radius $=1$ pixel) followed by image segmentation using the Otsu algorithm in ImageJ (https:// imagej.nih.gov/ij/). From the greyscale (8-bit) histogram of each sample, the degree of mineralisation $(\mathrm{dMn})$ was estimated as a dimensionless parameter, by integrating the product of each greyscale intensity, $i$, and the corresponding pixel count, for all values of $i$ (where $0<i \leq 255$ ), divided by the total number of pixels [29]. Mineralisation profiles were obtained from greyscale histograms. The data were binned in 16 greyscale intensity steps (i.e. $0-15,16-31,32-47$, etc.).

\section{Raman Spectroscopy}

Raman spectroscopy was performed using a confocal Raman microscope (WITec alpha300 R, Ulm, Germany), equipped with a $532 \mathrm{~nm}$ laser. The composition of the extracellular matrix was analysed at $20 \times 20 \mu \mathrm{m}$ regions of interest. For each sample, $8-10$ randomly selected locations were measured. On the surface of polished resin embedded blocks, the laser was focused down on to the sample using $a \times 100$ objective having a numerical aperture of 0.9. Spectra were collected in the $300-1800 \mathrm{~cm}^{-1}$ spectral range behind a $600 \mathrm{~mm}^{-1}$ grating, at a spectral resolution of $\sim 6 \mathrm{~cm}^{-1}$, an integration time of $3 \mathrm{~s}$ per pixel, and an isotropic pixel size of $5 \mu \mathrm{m}$. Background fluorescence subtraction was performed in WITEC Control FIVE software. Curve fitting and quantification of integral areas were done using MagicPlot (www.magicplot.com). The Raman metrics investigated included mineral crystallinity, taken as the reciprocal of the full-width at half-maximum (1/FWHM) of the $\nu_{1}$ $\mathrm{PO}_{4}{ }^{3-}$ peak, the carbonate-to-phosphate ratio $\left(\nu_{1} \mathrm{CO}_{3}{ }^{2-} / \nu_{2}\right.$ $\left.\mathrm{PO}_{4}{ }^{3-}\right)$, the mineral-to-matrix ratio $\left(\nu_{2} \mathrm{PO}_{4}{ }^{3-} /\right.$ amide III $)$, and the collagen crosslink ratio (CXLR), taken as the percentage area of the amide I sub-component at $\sim 1662 \mathrm{~cm}^{-1}[30$, 31]. To identify sub-component peaks in the amide I region, second-derivative spectra were calculated, followed by deconvolution of the $1540-1740 \mathrm{~cm}^{-1}$ envelope by Gaussian curve fitting. The amount of amino acid phenylalanine relative to the main phosphate peak at $959 \mathrm{~cm}^{-1}\left(\mathrm{Phe} / \nu_{1}\right.$ $\mathrm{PO}_{4}{ }^{3-}$ ) and the amount of amino acids proline/hydroxyproline (Pro + Hyp) were also investigated. The integral areas were $\nu_{1} \mathrm{PO}_{4}{ }^{3-}\left(960 \pm 15 \mathrm{~cm}^{-1}\right), \nu_{2} \mathrm{PO}_{4}{ }^{3-}\left(437 \pm 25 \mathrm{~cm}^{-1}\right), \nu_{1}$

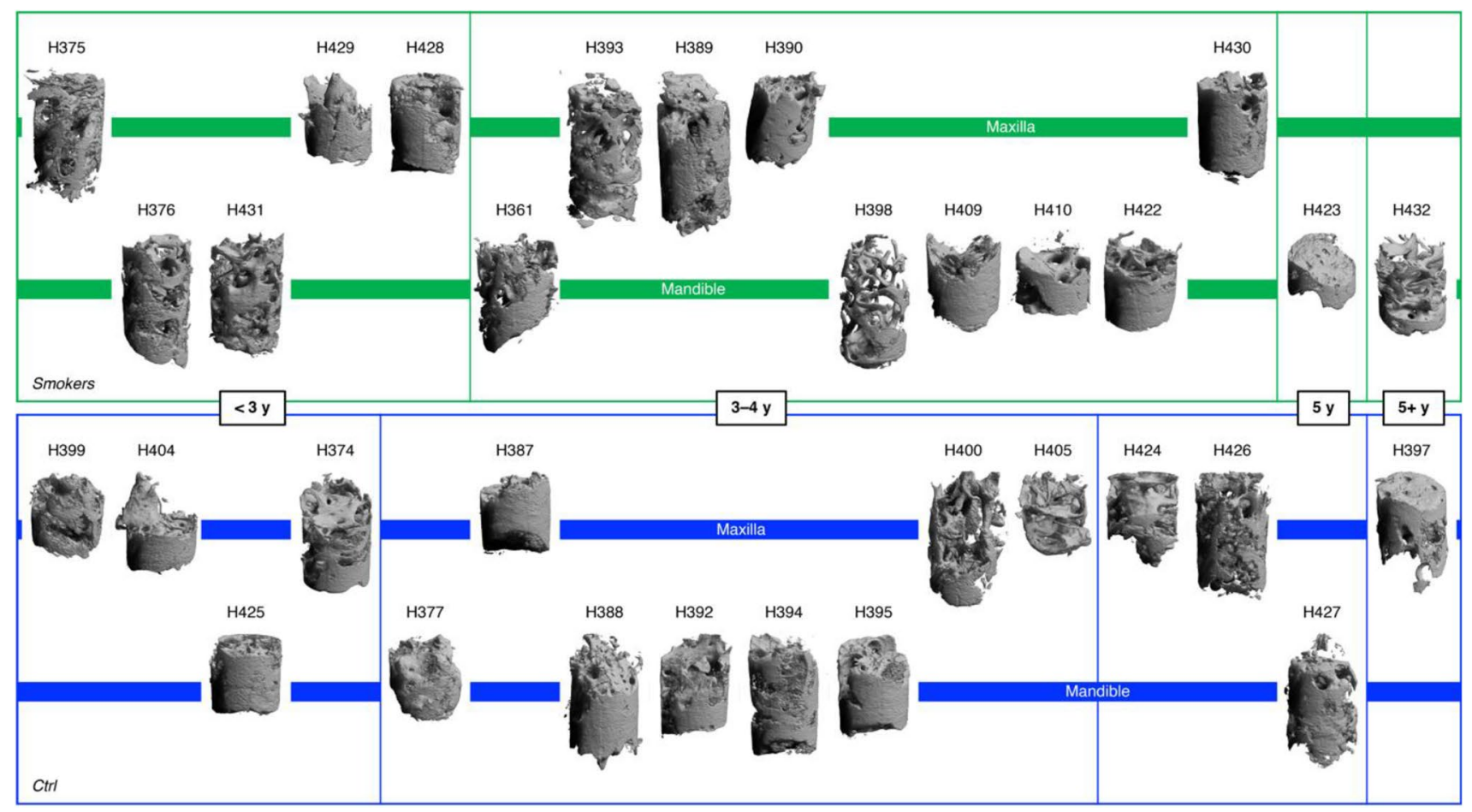

Fig. 1 X-ray micro-computed tomography overview of sample geometry and inter-individual heterogeneity of tissue microstructure in Smokers and $C t r l$ 
$\mathrm{CO}_{3}{ }^{2-}\left(1072 \pm 15 \mathrm{~cm}^{-1}\right)$, amide III $\left(1259 \pm 40 \mathrm{~cm}^{-1}\right)$, amide I $\left(1660 \pm 40 \mathrm{~cm}^{-1}\right)$, and Pro + Hyp $\left(850 \pm 30 \mathrm{~cm}^{-1}\right)$.

\section{Statistical Analysis}

The Kruskal-Wallis test was used for all statistical analyses (SPSS Statistics, v.25, IBM Corporation) between Smokers and $C t r l ; p$ values $<0.05$ were considered statistically significant. Mean values \pm standard deviations are presented.

\section{Results}

\section{Bone Microstructure}

In both Smokers and Ctrl, micro-CT revealed considerable inter-individual heterogeneity, varying between dense cortical to porous trabecular structure (Fig. 1), but with no apparent association with healing time or jaw. The BMD of Smokers $\left(1.20 \pm 0.06 \mathrm{~g} / \mathrm{mm}^{3}\right)$ and Ctrl $(1.21 \pm 0.08 \mathrm{~g} /$ $\left.\mathrm{mm}^{3}\right)$ was similar $(p=0.821)$. The BS/BV of Smokers $\left(16.96 \pm 5.42 \mathrm{~mm}^{-1}\right)$ and $\operatorname{Ctrl}\left(16.76 \pm 6.38 \mathrm{~mm}^{-1}\right)$ was also similar $(p=0.821)$ (Table 2).

Using BSE-SEM, high intra-individual and inter-individual heterogeneity in tissue microstructure were observed in both Smokers and Ctrl, including variation in mineral distribution and dimensions of non-lacunar porosity (i.e. blood vessels and marrow spaces). Regions of woven bone characterised by the presence of disorganised clusters of osteocytes were, typically, more prevalent during early healing (e.g. up to 16 months), while remodelled lamellar bone was predominant at longer healing periods (Fig. 2). The degree of mineralisation $(\mathrm{dMn})$ in Smokers $(112.97 \pm 10.38)$ and $C t r l$ $(112.78 \pm 15.75)$ was similar $(p=0.940)$. The mineralisation profiles were also similar ( $p>0.15$ for all bins) in Smokers and $\mathrm{Ctrl}$ (Fig. 3).

\section{Extracellular Matrix Composition}

Typical Raman spectral features of mineralised bone were seen for Smokers and Ctrl, The major peak/band assignments were $\nu_{1} \mathrm{PO}_{4}{ }^{3-}$ at $961 \mathrm{~cm}^{-1}, \nu_{2} \mathrm{PO}_{4}{ }^{3-}$ at $432 \mathrm{~cm}^{-1}$, $\nu_{4} \mathrm{PO}_{4}{ }^{3-}$ at $579 \mathrm{~cm}^{-1}$ and $\nu_{1} \mathrm{CO}_{3}{ }^{2-}$ at $1072 \mathrm{~cm}^{-1}$, amide III $\left(1219-1299 \mathrm{~cm}^{-1}\right)$, amide I $\left(1620-1700 \pm 40 \mathrm{~cm}^{-1}\right)$, Pro + Hyp $\left(820-880 \mathrm{~cm}^{-1}\right)$, and Phe $\left(1004 \mathrm{~cm}^{-1}\right)$. The mineral crystallinity, the carbonate-to-phosphate ratio, the mineral-to-matrix ratio, the collagen crosslink ratio, Phe, and Pro + Hyp in Smokers were similar ( $p>0.05$ for all) to Ctrl (Fig. 4, Table 3). No qualitative differences were noted between the maxilla and the mandible (Fig. 5).
Table 2 Bone mineral density (BMD) and bone surface-to-volume ratio $(\mathrm{BS} / \mathrm{BV})$ determined using $\mathrm{X}$-ray micro-computed tomography

\begin{tabular}{|c|c|c|c|}
\hline Group & Sample code & $\begin{array}{l}\text { BMD } \\
\mathrm{g} / \mathrm{mm}^{3}\end{array}$ & $\begin{array}{l}\mathrm{BS} / \mathrm{BV} \\
\mathrm{mm}^{-1}\end{array}$ \\
\hline \multirow[t]{16}{*}{ Smokers } & H375 & 1.171 & 28.210 \\
\hline & H389 & 1.197 & 15.427 \\
\hline & H390 & 1.319 & 10.715 \\
\hline & H393 & 1.224 & 20.866 \\
\hline & $\mathrm{H} 428$ & 1.101 & 14.261 \\
\hline & $\mathrm{H} 429$ & 1.070 & 14.322 \\
\hline & $\mathrm{H} 430$ & 1.191 & 12.544 \\
\hline & H361 & 1.236 & 18.748 \\
\hline & H376 & 1.218 & 19.905 \\
\hline & H398 & 1.248 & 21.147 \\
\hline & H409 & 1.233 & 9.916 \\
\hline & $\mathrm{H} 410$ & 1.213 & 13.658 \\
\hline & $\mathrm{H} 422$ & 1.237 & 13.938 \\
\hline & $\mathrm{H} 423$ & 1.240 & 11.708 \\
\hline & H431 & 1.146 & 26.477 \\
\hline & $\mathrm{H} 432$ & 1.227 & 19.540 \\
\hline \multirow[t]{16}{*}{ Ctrl } & H374 & 1.236 & 11.417 \\
\hline & H387 & 1.228 & 10.593 \\
\hline & H397 & 1.386 & 17.016 \\
\hline & H399 & 1.169 & 22.988 \\
\hline & $\mathrm{H} 400$ & 1.077 & 29.369 \\
\hline & H404 & 1.097 & 20.489 \\
\hline & $\mathrm{H} 405$ & 1.223 & 23.741 \\
\hline & $\mathrm{H} 424$ & 1.210 & 15.887 \\
\hline & H426 & 1.176 & 23.125 \\
\hline & H377 & 1.319 & 10.295 \\
\hline & H388 & 1.279 & 11.296 \\
\hline & H392 & 1.239 & 12.157 \\
\hline & H394 & 1.236 & 11.603 \\
\hline & H395 & 1.252 & 8.250 \\
\hline & $\mathrm{H} 425$ & 1.159 & 16.140 \\
\hline & $\mathrm{H} 427$ & 1.139 & 23.779 \\
\hline
\end{tabular}

\section{Discussion}

Inter-individual variation in the time needed for dental alveolar socket healing to complete is well-documented [32, 33]. Histological examination of alveolar bone biopsies from post-extraction sites in smokers and non-smokers reveals similar proportions of lamellar bone, woven bone, osteoid, bone marrow, and fibrous tissue [34]. Here, alveolar bone microstructure and the mineralised component in particular were probed using BSE-SEM, which in agreement with $\mathrm{BMD}$ values obtained using micro-CT, indicated similar mineralisation profiles and the overall degree of mineralisation (dMn) in Smokers and Ctrl. In contrast to histology, and with the exception of cells surrounded by bone mineral (e.g. 


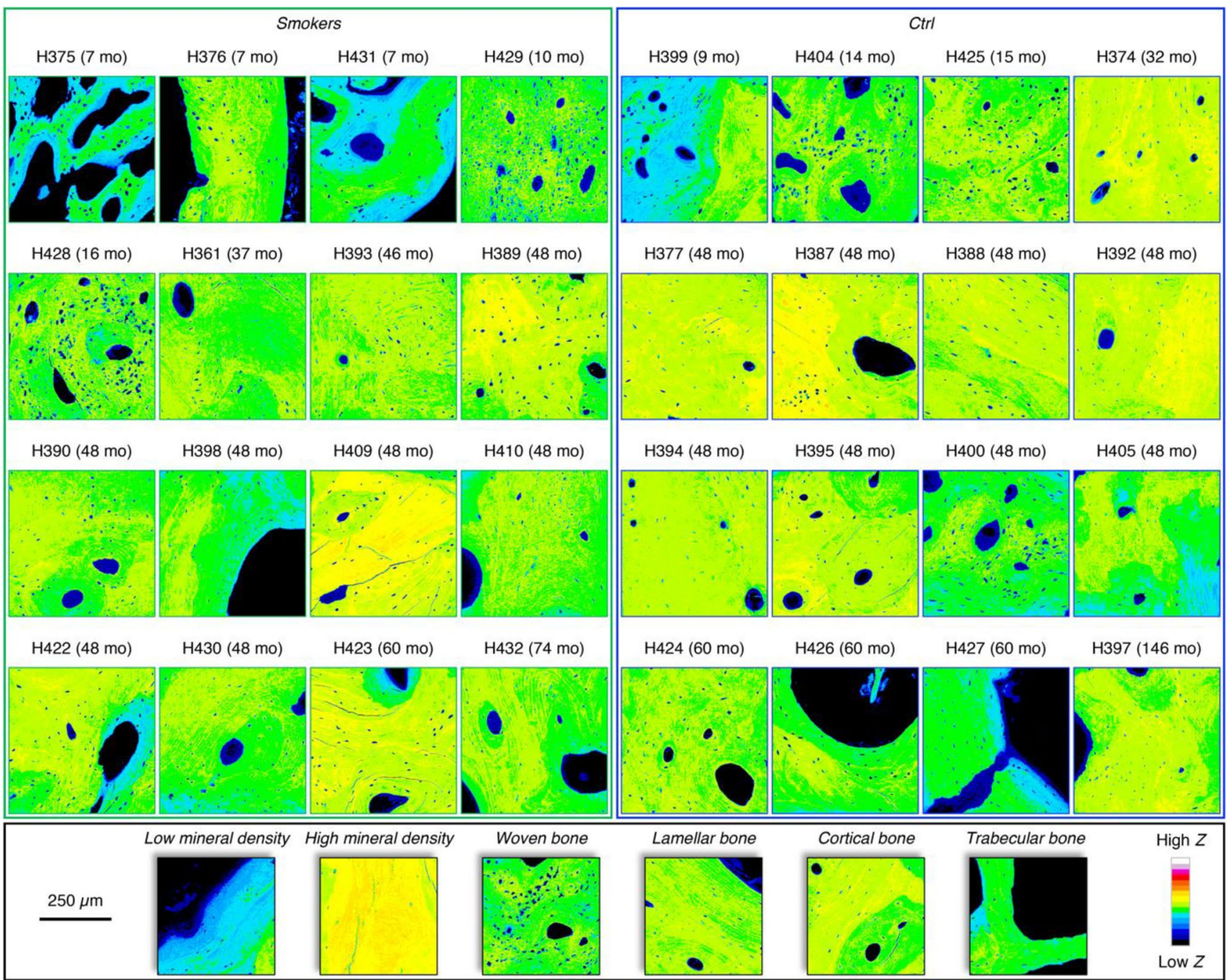

Fig. 2 Inter- and intra-individual heterogeneities in microstructure in Smokers and Ctrl, evaluated using backscattered electron scanning electron microscopy (BSE-SEM). For visual comparison, a 16-level lookup table has been applied. Post-extraction healing time is indicated in months (mo). Low Z: $\mathrm{i}=0$. High $\mathrm{Z}: \mathrm{i}=255$
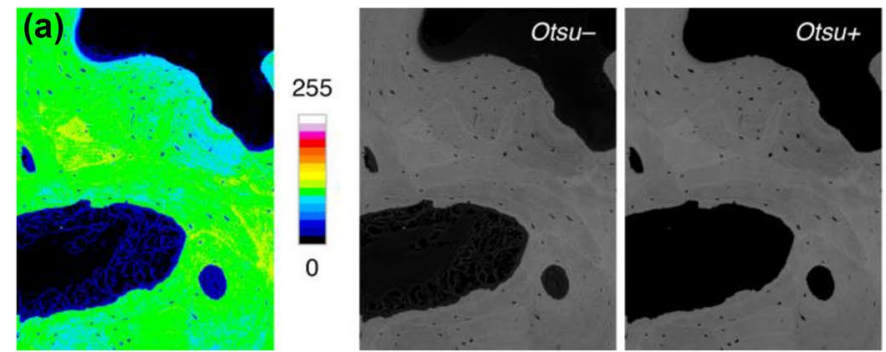

Fig. 3 Mineralisation profiles in Smokers and Ctrl. a Low Z- (atomic number) contrast areas arising from the embedding medium were filtered using the Otsu algorithm (BSE-SEM; 16-level lookup table). (b)

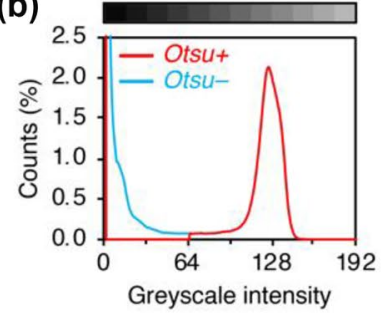

(c)

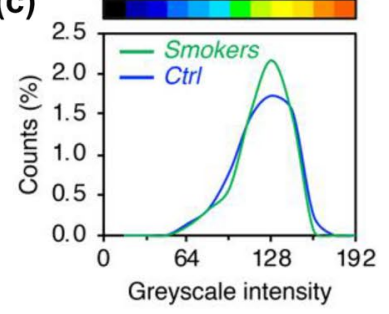

b Comparison of greyscale (8-bit) histograms of the same sample, $\mathrm{H} 430$, with $(\mathrm{Otsu}+)$ and without $(\mathrm{Otsu}-)$ Otsu filtering. c Mineralisation profiles binned in 16 greyscale intensity steps 

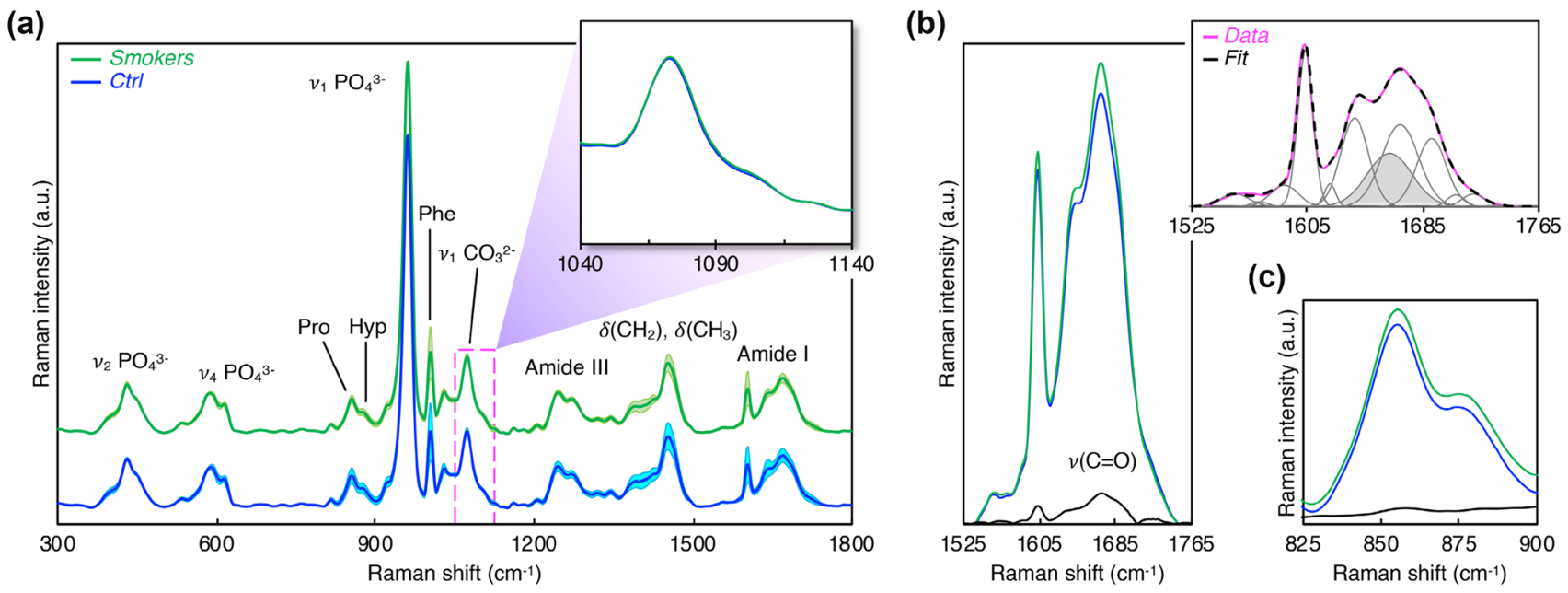

(d)
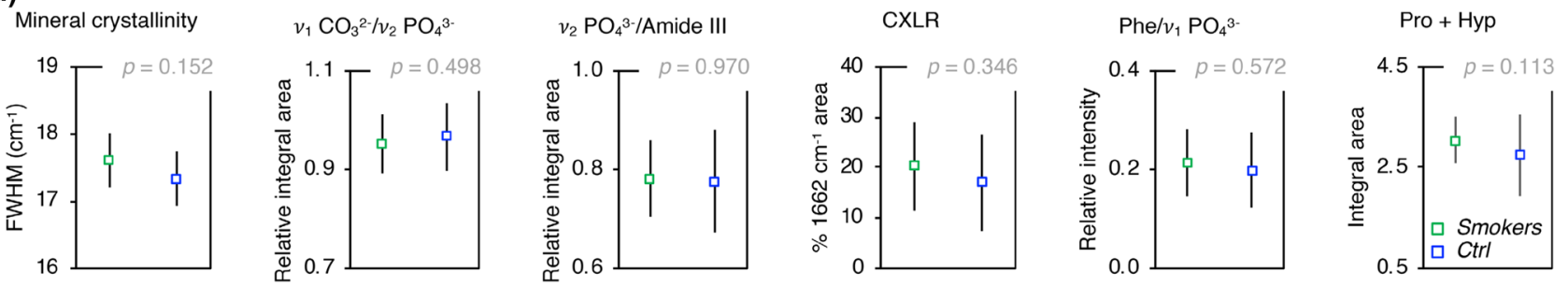

Fig. 4 a Average Raman spectra of Smokers $(n=16)$ and Ctrl $(n=16)$. Spectra are normalised to the intensity of the $960 \mathrm{~cm}^{-1}$ peak. Inset: Detail of the $1040-1140 \mathrm{~cm}^{-1}$ spectral region showing the $\nu_{1}$ $\mathrm{CO}_{3}{ }^{2-}$ bands. b Detail of the $1525-1765 \mathrm{~cm}^{-1}$ spectral region showing the amide I band and the absolute difference Raman spectrum (black line). Inset: Second-derivative spectrum (left) for identification of sub-component peaks in the amide I region and sub-component deconvolution of the $1540-1740 \mathrm{~cm}^{-1}$ envelope by fitting Gaussian

osteocytes and osteoblastic osteocytes), cellular components and intracellular contents cannot be observed directly using BSE imaging, and for this purpose, different contrast staining methods have been proposed [35].

On the extracellular matrix level, the individual constituents contribute greatly to bone strength and mechanical competence [36]. The strength of bone is governed not only by the mineral content, but is also influenced by the degree of mineral crystallinity $[37,38]$. The $\nu_{2} \mathrm{PO}_{4}{ }^{3-} /$ amide III ratio is the most reliable determinant of the mineral-to-matrix ratio [39], while mineral crystallinity can be estimated from both the position and the width of the $\nu_{1} \mathrm{PO}_{4}{ }^{3-}$ peak [40]. In synthetic carbonated apatites, an inverse relationship exists between the carbonate content and mineral crystallinity (i.e. the FWHM $\nu_{1} \mathrm{PO}_{4}{ }^{3-}$ increases) [41]. The crystallographic $c$-axis, (002) reflection measured using X-ray diffraction, shrinks from $\sim 86 \mathrm{~nm}\left(\right.$ FWHM $\left.\nu_{1} \mathrm{PO}_{4}{ }^{3-}=7.3 \mathrm{~cm}^{-1}\right)$ at $0.3 \mathrm{wt} \% \mathrm{CO}_{3}{ }^{2-}$ to $\sim 21 \mathrm{~nm}\left(\mathrm{FWHM} \nu_{1} \mathrm{PO}_{4}{ }^{3-}=18.2 \mathrm{~cm}^{-1}\right)$ at $10.3 \mathrm{wt} \% \mathrm{CO}_{3}{ }^{2-}$ [42]. In the $1000-1100 \mathrm{~cm}^{-1}$ region, the $v_{1} \mathrm{CO}_{3}{ }^{2-}$ peak overlaps the $\nu_{3} \mathrm{PO}_{4}{ }^{3-}$ band. The latter resolves into sub-components mainly at $1029 \mathrm{~cm}^{-1}$,

curves centred at $\sim 1555 \mathrm{~cm}^{-1}, \sim 1572 \mathrm{~cm}^{-1}, \sim 1589 \mathrm{~cm}^{-1}, \sim 1604 \mathrm{~cm}^{-1}$ $, \sim 1616 \mathrm{~cm}^{-1}, \sim 1621 \mathrm{~cm}^{-1}, \sim 1638 \mathrm{~cm}^{-1}, \sim 1662 \mathrm{~cm}^{-1}, \sim 1669 \mathrm{~cm}^{-1}, \sim$ $1691 \mathrm{~cm}^{-1}, \sim 1708 \mathrm{~cm}^{-1}, \sim 1720 \mathrm{~cm}^{-1}$, and $\sim 1736 \mathrm{~cm}^{-1}$. The percentage area of the amide I sub-component at $\sim 1662 \mathrm{~cm}^{-1}$ represents the collagen crosslink ratio. c Detail of the $825-900 \mathrm{~cm}^{-1}$ spectral region showing the Pro + Hyp bands and the absolute difference Raman spectrum (black line). d Raman metrics for extracellular matrix composition

$1040 \mathrm{~cm}^{-1}, 1047 \mathrm{~cm}^{-1}, 1053 \mathrm{~cm}^{-1}$, with weaker contributions at $1062 \mathrm{~cm}^{-1}$ and $1076 \mathrm{~cm}^{-1}$ that encroach upon the $\sim 1070-1072 \mathrm{~cm}^{-1} \nu_{1} \mathrm{CO}_{3}{ }^{2-}$ peak. In B-type $\mathrm{CO}_{3}{ }^{2-}$ (i.e. substituting for $\mathrm{PO}_{4}{ }^{3-}$ ) apatites, the $\nu_{3} \mathrm{PO}_{4}{ }^{3-}$ band is most obvious up to $\sim 3 \mathrm{wt} \% \mathrm{CO}_{3}{ }^{2-}$, but is almost completely enveloped by the $\nu_{1} \mathrm{CO}_{3}{ }^{2-}$ peak in bone [43], where the $\mathrm{CO}_{3}{ }^{2-}$ content is much higher, and typically around $7-9 \mathrm{wt} \%$ [44].

Intermolecular crosslinking governs the arrangement of collagen molecules within a fibril and ultimately imparts certain mechanical properties to the fibril [30]. The secondary structure of collagen can be interpreted from the amide I band [45, 46]. Alterations in collagen crosslinking, even when limited to microanatomical locations, can significantly influence the mechanical competence on the whole bone level, independent of changes in the mineral phase [47]. The collagen crosslink ratio, taken as the $\%$ area of the $1662 \mathrm{~cm}^{-1}$ sub-component, corresponds to biochemically determined pyridinoline content and represents pyridinoline trivalent crosslinks-one of the several naturally occurring crosslinks in collagen [30]. Here, the collagen crosslink 
Table 3 Raman metrics for extracellular matrix composition

\begin{tabular}{|c|c|c|c|c|c|c|c|}
\hline \multirow[t]{2}{*}{ Group } & \multirow[t]{2}{*}{ Sample code } & \multirow{2}{*}{$\begin{array}{l}\text { FWHM } \nu_{1} \mathrm{PO}_{4}^{3-} \\
\dagger\end{array}$} & \multirow{2}{*}{$\begin{array}{l}\nu_{1} \mathrm{CO}_{3}^{2-} / \\
\nu_{2} \mathrm{PO}_{4}^{3-} \\
\dagger \dagger\end{array}$} & \multirow{2}{*}{$\begin{array}{l}\mathrm{\nu}_{2} \mathrm{PO}_{4}^{3-} / \\
\text { amide III } \\
\dagger \dagger\end{array}$} & \multirow{2}{*}{$\begin{array}{l}\text { CXLR } \\
\#\end{array}$} & \multirow{2}{*}{$\begin{array}{l}\mathrm{Phe} / \nu_{1} \mathrm{PO}_{4}^{3-} \\
\neq\end{array}$} & \multirow[t]{2}{*}{$\begin{array}{l}\text { Pro + Hyp } \\
+\neq\end{array}$} \\
\hline & & & & & & & \\
\hline \multirow[t]{16}{*}{ Smokers } & H375 & 18.352 & 0.888 & 0.745 & 16.74 & 0.163 & 4.162 \\
\hline & H389 & 17.505 & 1.036 & 0.711 & 23.87 & 0.120 & 2.815 \\
\hline & H390 & 17.483 & 0.972 & 0.769 & 8.07 & 0.213 & 2.714 \\
\hline & H393 & 17.067 & 0.893 & 0.901 & 5.69 & 0.305 & 2.468 \\
\hline & $\mathrm{H} 428$ & 18.566 & 1.042 & 0.694 & 31.89 & 0.127 & 3.713 \\
\hline & $\mathrm{H} 429$ & 17.877 & 0.880 & 0.834 & 18.55 & 0.292 & 3.157 \\
\hline & H430 & 17.254 & 1.027 & 0.712 & 24.61 & 0.200 & 2.461 \\
\hline & H361 & 17.638 & 0.920 & 0.868 & 5.97 & 0.317 & 3.460 \\
\hline & H376 & 17.621 & 0.891 & 0.815 & 12.99 & 0.265 & 3.296 \\
\hline & H398 & 17.544 & 0.951 & 0.820 & 16.94 & 0.241 & 2.835 \\
\hline & H409 & 17.068 & 1.019 & 0.685 & 25.48 & 0.122 & 2.898 \\
\hline & H410 & 17.762 & 0.868 & 0.893 & 17.01 & 0.290 & 3.256 \\
\hline & $\mathrm{H} 422$ & 17.406 & 0.932 & 0.676 & 29.19 & 0.155 & 3.205 \\
\hline & $\mathrm{H} 423$ & 17.525 & 1.006 & 0.711 & 28.57 & 0.150 & 2.820 \\
\hline & $\mathrm{H} 431$ & 17.646 & 0.947 & 0.818 & 29.37 & 0.238 & 2.976 \\
\hline & $\mathrm{H} 432$ & 17.391 & 0.954 & 0.852 & 29.01 & 0.221 & 2.525 \\
\hline \multirow[t]{16}{*}{ Ctrl } & H374 & 17.309 & 0.956 & 0.942 & 23.61 & 0.208 & 2.626 \\
\hline & H387 & 17.060 & 1.087 & 0.714 & 29.78 & 0.085 & 2.075 \\
\hline & H397 & 17.486 & 0.965 & 0.964 & 5.00 & 0.278 & 2.609 \\
\hline & H399 & 17.475 & 0.848 & 0.689 & 21.05 & 0.302 & 3.098 \\
\hline & $\mathrm{H} 400$ & 17.806 & 0.860 & 0.579 & 14.00 & 0.224 & 4.372 \\
\hline & H404 & 17.718 & 0.930 & 0.750 & 31.20 & 0.302 & 4.239 \\
\hline & $\mathrm{H} 405$ & 17.706 & 0.943 & 0.816 & 15.58 & 0.250 & 3.119 \\
\hline & $\mathrm{H} 424$ & 17.379 & 1.062 & 0.697 & 26.17 & 0.126 & 2.315 \\
\hline & H426 & 17.588 & 0.996 & 0.837 & 29.02 & 0.118 & 2.019 \\
\hline & H377 & 17.052 & 0.969 & 0.791 & 20.48 & 0.126 & 2.295 \\
\hline & H388 & 16.709 & 0.907 & 0.833 & 6.68 & 0.221 & 2.050 \\
\hline & H392 & 16.735 & 0.968 & 0.840 & 9.16 & 0.167 & 1.831 \\
\hline & H394 & 16.629 & 0.984 & 0.825 & 5.76 & 0.184 & 1.722 \\
\hline & H395 & 17.166 & 1.054 & 0.716 & 4.05 & 0.128 & 2.622 \\
\hline & $\mathrm{H} 425$ & 17.755 & 1.025 & 0.625 & 8.32 & 0.143 & 3.362 \\
\hline & H427 & 17.839 & 0.901 & 0.806 & 21.32 & 0.327 & 3.497 \\
\hline \multicolumn{8}{|l|}{$\dagger \mathrm{cm}^{-1}$} \\
\hline \multicolumn{8}{|c|}{${ }^{\dagger \dagger}$ Relative integral area } \\
\hline \multicolumn{8}{|c|}{$\# \% 1662 \mathrm{~cm}^{-1}$ area } \\
\hline \multicolumn{8}{|c|}{ Relative intensity } \\
\hline${ }^{\ddagger}$ Integra & & & & & & & \\
\hline
\end{tabular}

ratio did not differ significantly between Smokers and Ctrl. Phe levels decline with increasing tissue maturity [48] and are typically recorded at around 9-12\% with respect to the intensity of the phosphate peak at $960 \mathrm{~cm}^{-1}[49,50]$ in periimplant bone. Here, Phe levels for Smokers (12-32\%) and Ctrl (8-33\%) were relatively higher, which reflects the contribution of rapidly formed woven bone. Pro + Hyp content also declines with tissue age [29], but did not differ between the two groups.
In composite materials, the volume fractions $(\mathrm{V})$ of the constituents, i.e. carbonated apatite and type-I collagen in bone, directly influence the physical properties. The Young's modulus (E) of the extracellular matrix can thus be predicted using the rule of mixtures equation $\left[\mathrm{E}_{c}=\mathrm{E}_{f} \mathrm{~V}_{f}+\mathrm{E}_{m}\left(1-\mathrm{V}_{f}\right)\right]$, where subscripts $c, f$, and $m$ represent the composite, the filler phase, and the matrix phase, respectively. Atomistic simulations indicate that a mineralised collagen fibril reaches maximum elastic modulus at a mineral density 
(a)

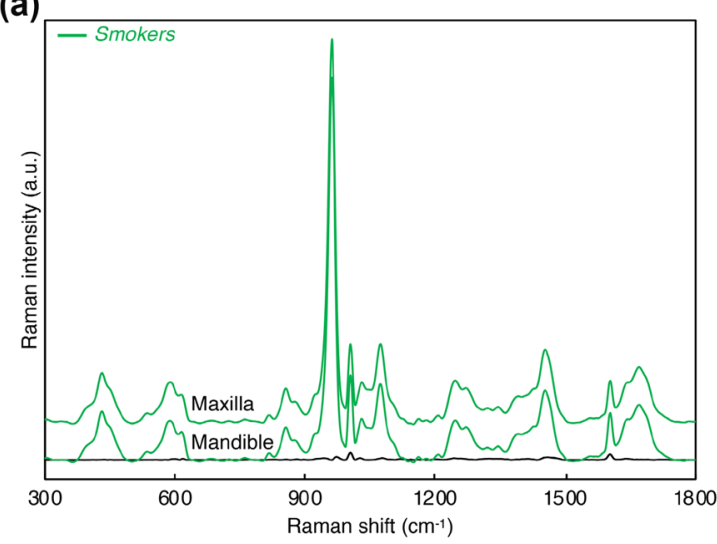

(b)

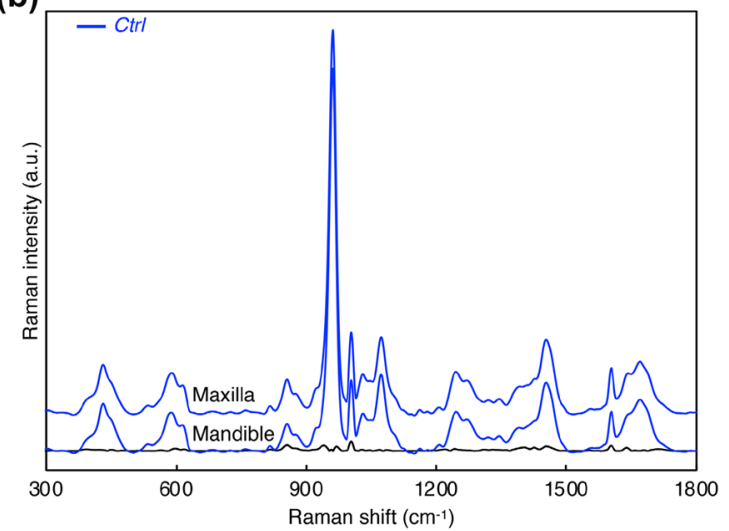

Fig. 5 Average Raman spectra and absolute difference Raman spectra (black lines) of alveolar bone biopsies from the maxilla and the mandible in a Smokers (maxilla, $n=7$; mandible, $n=9$ ), and $\mathbf{b} \operatorname{Ctrl}$ (maxilla, $n=9$; mandible, $n=7$ )

of $\sim 30 \%$ [51]. Similar mineral fraction values of $\sim 0.438$ (Smokers) and $\sim 0.435$ (Ctrl), estimated from the mineral-tomatrix ratios, in addition to similar collagen crosslink ratios, mineral crystallinity, and carbonate-to-phosphate ratios for Smokers and Ctrl, imply that both groups exhibit comparable mechanical competence. A recent study also reports no difference in the ultimate load and the energy-to-failure in vertebrae of mice exposed to cigarette smoke [52].

Smoking adversely affects various aspects of bone metabolism, directly and indirectly [53]. Through a dose-dependent inhibitory effect of nicotine on vascular endothelial growth factor (VEGF) production [54], impaired vascular perfusion of bone is particularly noteworthy [55]. Extracellular matrix composition, however, is not representative of biological events occurring at the bone surface or in the bone marrow. Bone specimens typically present substantial amounts of bone surface (characterised by the cellular components including osteoblasts and osteoclasts) and marrow spaces, where most of the osteogenic and inflammatory activity takes place. Therefore, there is minimal overlap between biomarkers of osteogenesis/inflammation (e.g. detected using gene expression analysis) and extracellular matrix composition. The present patient cohort is categorised as moderate intensity smokers with a $5.4 \%$ population prevalence in the USA [56]. It is not known whether these subjects are, in fact, exposed to a sub-critical dose of cigarette smoke and if a higher dose can be expected to induce detectable alterations in bone quality. It is, therefore, remarkable that in addition to bone microstructure, extracellular matrix compositional parameters, all, in Smokers remain comparable to Ctrl. It appears likely that in contrast to the effects reported on biomarkers of osteogenesis and inflammation [10,11,57], the extracellular matrix is less sensitive to the direct and indirect influences of cigarette smoke. Small patient cohorts in the present work preclude statistically reliable comparisons between maxillary and mandibular sites. Since bone turnover rates differ between maxillary and mandibular alveolar processes [58], disparate expression of osteogenic and/or inflammatory biomarkers between the two anatomical sites in smokers cannot be excluded. Further, the present observations do not exclude that cellular and molecular activities (i.e. tissue response) to trauma and the modulatory effects of different implant properties on these activities may differ between Smokers and Ctrl. In fact, the implant surface properties tend to play an important role in the expression of markers of inflammation and bone formation as well as marginal bone loss in smokers [11-13, 15]. Nevertheless, we demonstrate that bone microstructure and extracellular matrix composition are not affected significantly by smoking. Poor bone quality is, therefore, not a plausible cause for implant failures in moderate-to-heavy smokers.

A potential pitfall of this work is chemical fixation using formalin, which is deemed sub-optimal for spectroscopic analysis of bone. Compared to unprocessed and/or cryo-sectioned tissues, and fixation with $70-100 \%$ ethanol, glycerol, etc., formalin may affect various compositional parameters [59]. However, both Smokers and Ctrl samples were processed in an identical manner, limiting experimental error(s) attributable to formalin fixation.

\section{Conclusions}

Alveolar bone regeneration following tooth extraction follows similar patterns in Smokers and Ctrl, with a predominance of disorganised woven bone during the early stages that is later replaced by organised lamellar bone. This study demonstrates, for the first time, that bone microstructure and the relative contents and specific characteristics of the inorganic and the organic phases are not significantly altered by moderate-to-heavy smoking. In contrast to the various cells 
found in bone that tend to respond by producing a number of osteogenic and inflammatory biomarkers, the mineralised extracellular matrix, which itself is a product of cellular and physicochemical/biophysical processes, appears less sensitive to the direct and indirect effects of smoking.

Acknowledgements Open access funding provided by University of Gothenburg. The authors wish to thank Lena Emanuelsson and MärtaSofie Geijer for technical assistance. Financial support is acknowledged from the Swedish Research Council (2018-02891), Svenska Sällskapet för Medicinsk Forskning (SSMF) postdoctoral scholarship, the Swedish state under the agreement between the Swedish government and the county councils, the ALF agreement (ALFGBG-725641), the Adlerbertska Foundation, the IngaBritt and Arne Lundberg Foundation, the Wilhelm and Martina Lundgren Foundation, Stiftelsen Konrad och Helfrid Johanssons fond, the Dr. Felix Neubergh Foundation, Promobilia, the Hjalmar Svensson Foundation, Futurum-Academy for Health and Care, Jönköping County Council, Jönköping, the Osteology Foundation (YRG 17-047), and the Materials Science Area of Advance at Chalmers and the Department of Biomaterials, University of Gothenburg within the Strategic Research Area initiative launched by the Swedish Government.

\section{Compliance with Ethical Standards}

Conflict of interest Furqan A. Shah, Shariel Sayardoust, Omar Omar, Peter Thomsen, and Anders Palmquist declare that they have no conflict of interest.

Human and Animal Rights and Informed Consent The study protocol was approved by the Institutional Review Board at the University of Linköping (Dnr 2016/319-31). Informed consent was obtained from all participants. The study was conducted in accordance with the guidelines of Good Clinical Practice for Trials on Medicinal Products in the European Community, the International Conference on Harmonisation (ICH) guideline for Good Clinical Practice, the Declaration of Helsinki, and the CONSORT guidelines for clinical studies.

Open Access This article is distributed under the terms of the Creative Commons Attribution 4.0 International License (http://creativeco mmons.org/licenses/by/4.0/), which permits unrestricted use, distribution, and reproduction in any medium, provided you give appropriate credit to the original author(s) and the source, provide a link to the Creative Commons license, and indicate if changes were made.

\section{References}

1. Bilano V, Gilmour S, Moffiet T, d'Espaignet ET, Stevens GA, Commar A, Tuyl F, Hudson I, Shibuya K (2015) Global trends and projections for tobacco use, 1990-2025: an analysis of smoking indicators from the WHO comprehensive information systems for tobacco control. Lancet 385(9972):966-976. https://doi. org/10.1016/s0140-6736(15)60264-1

2. Kuper H, Adami HO, Boffetta P (2002) Tobacco use, cancer causation and public health impact. J Intern Med 251(6):455-466. https://doi.org/10.1046/j.1365-2796.2002.00993.x

3. Goodchild M, Nargis N, Tursan d'Espaignet E (2017) Global economic cost of smoking-attributable diseases. Tob Control. https:// doi.org/10.1136/tobaccocontrol-2016-053305

4. Kopiczko A, Gryko K, Łopuszańska-Dawid M (2018) Bone mineral density, hand grip strength, smoking status and physical activity in polish young men. Homo 69(4):209-216. https://doi. org/10.1016/j.jchb.2018.08.003

5. Johnson JE, Troy KL (2018) Moderate-to-heavy smoking in women is potentially associated with compromised cortical porosity and stiffness at the distal radius. Arch Osteoporos 13(1):89. https://doi.org/10.1007/s11657-018-0504-y

6. Johnson GK, Guthmiller JM (2007) The impact of cigarette smoking on periodontal disease and treatment. Periodontol 2000 44(1):178-194. https://doi.org/10.1111/j.1600-0757.2007.00212 .x

7. Raes S, Rocci A, Raes F, Cooper L, De Bruyn H, Cosyn J (2015) A prospective cohort study on the impact of smoking on soft tissue alterations around single implants. Clin Oral Implants Res 26(9):1086-1090. https://doi.org/10.1111/clr.12405

8. Moraschini V, Poubel LA, Ferreira VF, Barboza Edos S (2015) Evaluation of survival and success rates of dental implants reported in longitudinal studies with a follow-up period of at least 10 years: a systematic review. Int J Oral Maxillofac Surg 44(3):377-388. https://doi.org/10.1016/j.ijom.2014.10.023

9. Jung RE, Zembic A, Pjetursson BE, Zwahlen M, Thoma DS (2012) Systematic review of the survival rate and the incidence of biological, technical, and aesthetic complications of single crowns on implants reported in longitudinal studies with a mean follow-up of 5 years. Clin Oral Implants Res 23(Suppl 6):2-21. https://doi. org/10.1111/j.1600-0501.2012.02547.x

10. Campos JM, Prati AJ, Cirano FR, Pimentel SP, Pastore GP, Pecorari VG, Ribeiro FV, Casati MZ, Casarin RC (2015) Smoking modulates gene expression of type i collagen, bone sialoprotein, and osteocalcin in human alveolar bone. J Oral Maxillofac Surg 73(11):2123-2131. https://doi.org/10.1016/j.joms.2015.06.168

11. Sayardoust S, Omar O, Norderyd O, Thomsen P (2018) Implantassociated gene expression in the jaw bone of smokers and nonsmokers: a human study using quantitative qPCR. Clin Oral Implants Res 29(9):937-953. https://doi.org/10.1111/clr.13351

12. Sayardoust S, Omar O, Thomsen P (2017) Gene expression in peri-implant crevicular fluid of smokers and nonsmokers. 1 . The early phase of osseointegration. Clin Implant Dent Relat Res 19(4):681-693. https://doi.org/10.1111/cid.12486

13. Sayardoust S, Omar O, Norderyd O, Thomsen P (2017) Clinical, radiological, and gene expression analyses in smokers and non-smokers, Part 2: RCT on the late healing phase of osseointegration. Clin Implant Dent Relat Res 19(5):901-915. https:// doi.org/10.1111/cid.12514

14. Chrcanovic BR, Albrektsson T, Wennerberg A (2015) Smoking and dental implants: a systematic review and meta-analysis. J Dent 43(5):487-498. https://doi.org/10.1016/j.jdent .2015 .03 .003

15. Sayardoust S, Gröndahl K, Johansson E, Thomsen P, Slotte C (2013) Implant survival and marginal bone loss at turned and oxidized implants in periodontitis-susceptible smokers and never-smokers: a retrospective, clinical, radiographic casecontrol study. J Periodontol 84(12):1775-1782. https://doi. org/10.1902/jop.2013.120608

16. Hinode D, Tanabe S, Yokoyama M, Fujisawa K, Yamauchi E, Miyamoto Y (2006) Influence of smoking on osseointegrated implant failure: a meta-analysis. Clin Oral Implants Res 17(4):473-478. https://doi.org/10.111 $1 / \mathrm{j} .1600-0501.2005 .01244 . x$

17. De Bruyn H, Collaert B (1994) The effect of smoking on early implant failure. Clin Oral Implants Res 5(4):260-264

18. Bergström J, Eliasson S, Dock J (2000) A 10-year prospective study of tobacco smoking and periodontal health. J Periodontol 71(8):1338-1347. https://doi.org/10.1902/jop.2000.71.8.1338

19. Baljoon M, Natto S, Bergström J (2005) Long-term effect of smoking on vertical periodontal bone loss. J Clin 
Periodontol 32(7):789-797. https://doi.org/10.1111/j.1600051X.2005.00765.X

20. Lindquist LW, Carlsson GE, Jemt T (1997) Association between marginal bone loss around osseointegrated mandibular implants and smoking habits: a 10-year follow-up study. J Dent Res 76(10):1667-1674. https://doi.org/10.1177/002203459707601 00801

21. Lambert PM, Morris HF, Ochi S (2000) The influence of smoking on 3-year clinical success of osseointegrated dental implants. Ann Periodontol 5(1):79-89. https://doi.org/10.1902/ annals.2000.5.1.79

22. Bain CA (2003) Implant installation in the smoking patient. Periodontol 2000 33(1):185-193. https://doi.org/10.104 6/j.0906-6713.2003.03315.x

23. Tsigarida AA, Dabdoub SM, Nagaraja HN, Kumar PS (2015) The influence of smoking on the peri-implant microbiome. J Dent Res 94(9):1202-1217. https://doi.org/10.1177/00220 34515590581

24. Correa MG, Gomes Campos ML, César-Neto JB, Casati MZ, Nociti FH, Sallum EA (2009) Histometric evaluation of bone around titanium implants with different surface treatments in rats exposed to cigarette smoke inhalation. Clin Oral Implant Res 20(6):588-593. https://doi.org/10.1111/j.1600-0501.2008.01695 . $\mathrm{x}$

25. Nociti Junior FH, Cesar Neto JB, Carvalho MD, Sallum EA, Sallum AW (2002) Intermittent cigarette smoke inhalation may affect bone volume around titanium implants in rats. J Periodontol 73(9):982-987. https://doi.org/10.1902/jop.2002.73.9.982

26. Carvalho MD, Benatti BB, Cesar-Neto JB, Nociti FH Jr, da Rocha Nogueira Filho G, Casati MZ, Sallum EA (2006) Effect of cigarette smoke inhalation and estrogen deficiency on bone healing around titanium implants: a histometric study in rats. J Periodontol 77(4):599-605. https://doi.org/10.1902/jop.2006.050190

27. Saldanha JB, Casati MZ, Neto FH, Sallum EA, Nociti FH Jr (2006) Smoking may affect the alveolar process dimensions and radiographic bone density in maxillary extraction sites: a prospective study in humans. J Oral Maxillofac Surg 64(9):1359-1365. https://doi.org/10.1016/j.joms.2006.05.021

28. Lekholm U, Zarb GA (1985) Patient selection and preparation. In: Brånemark PI, Zarb GA, Tomas A (eds) Tissue integrated prostheses: osseointegration in clinical dentistry. Quintessence, Chicago p, pp 199-209

29. Shah FA, Stoica A, Cardemil C, Palmquist A (2018) Multiscale characterization of cortical bone composition, microstructure, and nanomechanical properties in experimentally induced osteoporosis. J Biomed Mater Res A 106(4):997-1007. https://doi. org/10.1002/jbm.a.36294

30. Gamsjaeger S, Robins SP, Tatakis DN, Klaushofer K, Paschalis EP (2017) Identification of pyridinoline trivalent collagen cross-links by Raman micro spectroscopy. Calcif Tissue Int 100(6):565-574. https://doi.org/10.1007/s00223-016-0232-5

31. Shah FA, Sayardoust S, Thomsen P, Palmquist A (2019) Extracellular matrix composition during bone regeneration in the human dental alveolar socket. Bone 127:244-249. https://doi. org/10.1016/j.bone.2019.06.003

32. Trombelli L, Farina R, Marzola A, Bozzi L, Liljenberg B, Lindhe J (2008) Modeling and remodeling of human extraction sockets. J Clin Periodontol 35(7):630-639. https://doi.org/10.1111/j.1600051X.2008.01246.x

33. Araújo MG, Silva CO, Misawa M (2000) Sukekava F (2015) Alveolar socket healing: what can we learn? Periodontol 68(1):122134. https://doi.org/10.1111/prd.12082

34. Lindhe J, Cecchinato D, Bressan EA, Toia M, Araújo MG, Liljenberg B (2012) The alveolar process of the edentulous maxilla in periodontitis and non-periodontitis subjects. Clin Oral Implants
Res 23(1):5-11. https://doi.org/10.1111/j.1600-0501.2011.02205 .X

35. Shah FA, Ruscsák K, Palmquist A (2019) 50 years of scanning electron microscopy of bone-a comprehensive overview of the important discoveries made and insights gained into bone material properties in health, disease, and taphonomy. Bone Res 7(1):15

36. Bala Y, Seeman E (2015) Bone's material constituents and their contribution to bone strength in health, disease, and treatment. Calcif Tissue Int 97(3):308-326. https://doi.org/10.1007/s0022 3-015-9971-y

37. Morris MD, Mandair GS (2011) Raman assessment of bone quality. Clin Orthop Relat Res 469(8):2160-2169. https://doi. org/10.1007/s11999-010-1692-y

38. Yerramshetty JS, Akkus O (2008) The associations between mineral crystallinity and the mechanical properties of human cortical bone. Bone 42(3):476-482. https://doi.org/10.1016/j. bone.2007.12.001

39. Roschger A, Gamsjaeger S, Hofstetter B, Masic A, Blouin S, Messmer P, Berzlanovich A, Paschalis EP, Roschger P, Klaushofer K, Fratzl P (2014) Relationship between the v(2)PO(4)/amide III ratio assessed by Raman spectroscopy and the calcium content measured by quantitative backscattered electron microscopy in healthy human osteonal bone. J Biomed Opt 19(6):065002. https ://doi.org/10.1117/1.jbo.19.6.065002

40. Querido W, Ailavajhala R, Padalkar M, Pleshko N (2018) Validated approaches for quantification of bone mineral crystallinity using transmission fourier transform infrared (FT-IR), attenuated total reflection (ATR) FT-IR, and Raman spectroscopy. Appl Spectrosc 72(11):1581-1593. https://doi.org/10.1177/0003702818 789165

41. Wang M, Qian R, Bao M, Gu C, Zhu P (2018) Raman, FT-IR and XRD study of bovine bone mineral and carbonated apatites with different carbonate levels. Mater Lett 210:203-206. https://doi. org/10.1016/j.matlet.2017.09.023

42. McElderry J-DP, Zhu P, Mroue KH, Xu J, Pavan B, Fang M, Zhao G, McNerny E, Kohn DH, Franceschi RT, Holl MMB, Tecklenburg MMJ, Ramamoorthy A, Morris MD (2013) Crystallinity and compositional changes in carbonated apatites: evidence from 31P solid-state NMR, Raman, and AFM analysis. J Solid State Chem 206:192-198. https://doi.org/10.1016/j.jssc.2013.08.011

43. Awonusi A, Morris MD, Tecklenburg MM (2007) Carbonate assignment and calibration in the Raman spectrum of apatite. Calcif Tissue Int 81(1):46-52. https://doi.org/10.1007/s0022 3-007-9034-0

44. Penel G, Delfosse C, Descamps M, Leroy G (2005) Composition of bone and apatitic biomaterials as revealed by intravital Raman microspectroscopy. Bone 36(5):893-901. https://doi. org/10.1016/j.bone.2005.02.012

45. Frushour BG, Koenig JL (1975) Raman scattering of collagen, gelatin, and elastin. Biopolymers 14(2):379-391. https://doi. org/10.1002/bip.1975.360140211

46. Janko M, Zink A, Gigler AM, Heckl WM, Stark RW (2010) Nanostructure and mechanics of mummified type I collagen from the 5300-year-old tyrolean iceman. Proc Biol Sci 277(1692):23012309. https://doi.org/10.1098/rspb.2010.0377

47. Paschalis EP, Tatakis DN, Robins S, Fratzl P, Manjubala I, Zoehrer R, Gamsjaeger S, Buchinger B, Roschger A, Phipps R, Boskey AL, Dall'Ara E, Varga P, Zysset P, Klaushofer K, Roschger P (2011) Lathyrism-induced alterations in collagen cross-links influence the mechanical properties of bone material without affecting the mineral. Bone 49(6):1232-1241. https://doi. org/10.1016/j.bone.2011.08.027

48. Shah FA, Snis A, Matic A, Thomsen P, Palmquist A (2016) 3D printed Ti6Al4 V implant surface promotes bone maturation and retains a higher density of less aged osteocytes at the bone-implant 
interface. Acta Biomater 30:357-367. https://doi.org/10.1016/j. actbio.2015.11.013

49. Shah FA (2019) Micro-Raman spectroscopy reveals the presence of octacalcium phosphate and whitlockite in association with bacteria-free zones within the mineralized dental biofilm. Microsc Microanal 25(1):129-134. https://doi.org/10.1017/S143192761 8015659

50. Shah FA, Lee BEJ, Tedesco J, Larsson Wexell C, Persson C, Thomsen P, Grandfield K, Palmquist A (2017) Micrometer-sized magnesium whitlockite crystals in micropetrosis of bisphosphonate-exposed human alveolar bone. Nano Lett 17(10):6210-6216. https://doi.org/10.1021/acs.nanolett.7b02888

51. Depalle B, Qin Z, Shefelbine SJ, Buehler MJ (2016) Large deformation mechanisms, plasticity, and failure of an individual collagen fibril with different mineral content. J Bone Miner Res 31(2):380-390. https://doi.org/10.1002/jbmr.2705

52. Sasaki M, Chubachi S, Kameyama N, Sato M, Haraguchi M, Miyazaki M, Takahashi S, Nakano T, Kuroda Y, Betsuyaku T, Matsuo K (2018) Effects of long-term cigarette smoke exposure on bone metabolism, structure, and quality in a mouse model of emphysema. PLoS ONE 13(1):e0191611. https://doi.org/10.1371/ journal.pone.0191611

53. Yoon V, Maalouf NM, Sakhaee K (2012) The effects of smoking on bone metabolism. Osteoporos Int 23(8):2081-2092. https://doi. org/10.1007/s00198-012-1940-y

54. Ma L, Zheng LW, Sham MH, Cheung LK (2010) Uncoupled angiogenesis and osteogenesis in nicotine-compromised bone healing.
J Bone Miner Res 25(6):1305-1313. https://doi.org/10.1002/ jbmr.19

55. Marenzana M, Arnett TR (2013) The key role of the blood supply to bone. Bone Res 1(3):203-215. https://doi.org/10.4248/br201 303001

56. Pierce JP, Messer K, White MM, Cowling DW, Thomas DP (2011) Prevalence of heavy smoking in California and the United States, 1965-2007. JAMA 305(11):1106-1112. https://doi.org/10.1001/ jama.2011.334

57. Bielemann AM, Marcello-Machado RM, Leite FRM, Martinho FC, Chagas-Junior OL, Del Bel Antoninha, Cury A, Faot F (2018) Comparison between inflammation-related markers in peri-implant crevicular fluid and clinical parameters during osseointegration in edentulous jaws. Clin Oral Investig 22(1):531-543. https://doi.org/10.1007/s00784-017-2169-0

58. Huja SS, Fernandez SA, Hill KJ, Li Y (2006) Remodeling dynamics in the alveolar process in skeletally mature dogs. Anat Rec A 288(12):1243-1249. https://doi.org/10.1002/ar.a.20396

59. Aparicio S, Doty SB, Camacho NP, Paschalis EP, Spevak L, Mendelsohn R, Boskey AL (2002) Optimal methods for processing mineralized tissues for fourier transform infrared microspectroscopy. Calcif Tissue Int 70(5):422-429. https://doi.org/10.1007/ s00223-001-1016-z

Publisher's Note Springer Nature remains neutral with regard to jurisdictional claims in published maps and institutional affiliations. 